\title{
A missa e a fábrica: tentativas de controle dos espaços das igrejas pelos bispos coloniais paulistas (1745-1796)
}

Dalila ZANON ${ }^{\bullet}$

Resumo: As cartas pastorais dos bispos coloniais e os capítulos de visitas pastorais registrados nos livros de tombo das freguesias dos bispados fornecem-nos subsídios acerca, entre outros assuntos, da implementação dos decretos tridentinos na Colônia setecentista. Tais decretos, provenientes do Concílio de Trento realizado pela Igreja Católica no século XVI, deveriam nortear a atuação de todos os elementos da hierarquia eclesiástica nos reinos católicos. Aos bispos, contudo, ficou a responsabilidade da implantação dos dispositivos tridentinos, executando-os e exigindo que em todos os âmbitos de sua jurisdição fossem observados. Da leitura e análise das pastorais e dos capítulos das visitas pastorais dos bispos de São Paulo entre 1745 e 1796 - deparamo-nos com uma orientação episcopal alinhada com os decretos tridentinos. Neste artigo focalizaremos dois aspectos da administração dos bispos paulistas: a cerimônia da missa e a administração das fábricas das igrejas.

Palavras-chave: Igreja Católica; Bispos do século XVIII; Cartas pastorais.

\section{Introdução}

As cartas pastorais dos bispos coloniais e os capítulos de visitas pastorais registrados nos livros de tombo das freguesias dos bispados fornecem-nos subsídios acerca, entre outros assuntos, da implementação dos decretos tridentinos na Colônia

\footnotetext{
- Doutoranda em História Cultural - Programa de Pós-graduação em História - Instituto de Filosofia e Ciências Humanas - UNICAMP 13081-970 - Campinas - SP - Brasil. E-mail: zanondalila@yahoo.com.br 
setecentista. Tais decretos, provenientes do Concílio de Trento realizado pela Igreja Católica no século XVI, deveriam nortear a atuação de todos os elementos da hierarquia eclesiástica nos reinos católicos. Aos bispos, contudo, ficou a responsabilidade da implantação dos dispositivos tridentinos, executando-os e exigindo que em todos os âmbitos de sua jurisdição fossem observados. Da leitura e análise das pastorais e dos capítulos das visitas pastorais dos bispos de São Paulo - entre 1745 e 1796 - deparamo-nos com uma orientação episcopal alinhada com os decretos tridentinos.

Interessa-nos, pois, demonstrar a presença dessa orientação no bispado de São Paulo através dos documentos citados, bem como, situar o tema da implantação da reforma tridentina e da atuação da Igreja na historiografia colonial.

Neste artigo focalizaremos dois aspectos da administração dos bispos paulistas: em relação à realização da cerimônia da missa aos domingos e dias santos e em relação à administração do patrimônio das igrejas e capelas depositado nas chamadas fábricas. Tais aspectos marcam a atuação não apenas espiritual mas também material da Igreja na Colônia.

\section{A historiografia colonial e a reforma tridentina}

A Reforma Católica no século XVI tem como uma de suas mais altas expressões no plano institucional o Concílio de Trento, ocorrido na Europa no século XVI. Contudo, não devemos reduzir o movimento da reforma da Igreja católica somente neste episódio. Alguns autores afirmam que desde o século XII iniciouse um movimento reformador da Igreja e, da mesma forma, o século XVI não marcou o seu fim. O período quinhentista marcou a institucionalização da reforma, porém foram necessários muitos séculos para ser implantada.

Essa visão de longa duração da Reforma Católica foi fundamentada, segundo Lana Lage da Gama Lima, nos estudos sobre história da religião do sociólogo francês Gabriel Le Bras na década de 30 . Na década de 70 a autora destacou os autores 
A MISSA E A FÁBRICA: TENTATIVAS DE CONTROLE DOS ESPAÇOS...

John Bossy e Jean Delumeau como os estudiosos que impulsionaram a revisão sobre o tema da Reforma Católica. Tais autores influenciados pelo movimento da Nouvelle Histoire trouxeram para os estudos da Reforma Católica a preocupação com a longa duração, com o cotidiano e com a atenção para o caráter global da vida social, retirando dos estudos da história religiosa o destaque para a vida dos papas, os grandes debates teológicos e a política eclesiástica dos reis. ${ }^{1}$

Segundo Jean Delumeau pode-se dividir o movimento de Reforma da Igreja em duas fases: a da pré-reforma e aquela que resultou na abertura dos trabalhos em Trento no século XVI. Os movimentos precursores da Reforma da Igreja datam do século XII. Algumas expressões desses movimentos, conforme Delumeau, foram a Devotio Moderna, os Irmãos de Vida Comum e um número expressivo de bispos que iniciaram uma reforma moralizante do clero em suas dioceses. ${ }^{2}$ Esses movimentos precursores levaram a Igreja, sobretudo a partir do século XV, a constatar o afastamento do clero e dos fiéis das leis da Igreja. Descobriu-se uma religião folclorizada, um comportamento moral dos fiéis inadequado aos mandamentos da Igreja, e um clero paroquial não somente despreparado, mas integrado à vida da comunidade e caracterizado pelos mesmos vícios dos fiéis. Tais fatores levaram a Igreja a institucionalizar a reforma, iniciada antes por movimentos dispersos. ${ }^{3}$

A constatação da decadência moral da Igreja não deve ser vista, segundo Leandro Karnal, como um momento único da história da Igreja. Para Karnal o movimento da Igreja católica no século XVI assemelha-se a outros momentos de reforma na história dessa instituição. Em suas palavras: "todos os períodos da história da Igreja são períodos de embate entre a decadência e a reação à decadência. $O$ conceito de decadência remete a um problema: a existência de um período perfeito e áureo. Ora, este período jamais existiu na história da Igreja." Portanto, o embate entre as forças ordenadoras e as forças resistentes a tal ordenação é o que constitui o próprio cristianismo historicamente. ${ }^{4}$ Entendemos, portanto, acordando com Karnal, que o estudo da Reforma Católica, seja no século XVI ou nos 
posteriores, atendem à preocupação de historicizarmos um dos movimentos reformadores da Igreja. Estamos preocupados com a dimensão histórica dessa instituição: sua presença e intervenção num determinado tempo e espaço, sem nos atermos à idéia presente em Delumeau de que foi neste momento que a Igreja impôs uma renovação de seus quadros e dos costumes dos fiéis de forma definitiva.

Ainda assim a obra de Delumeau traz apontamentos históricos importantes para o nosso estudo. Para ele a reforma preconizada por Trento foi introduzida com grande lentidão nos costumes e instituições. De fato, segundo este autor, o momento que se fez sentir na Europa os decretos tridentinos corresponde à segunda metade do século XVII e início do XVIII. ${ }^{5}$ As dificuldades de aplicação dos decretos tridentinos nos reinos cristãos foram apontadas por Delumeau mais no campo disciplinar do que dogmático. O autor afirmou que os decretos dogmáticos aprovados pela assembléia de Trento foram, com notável unanimidade, adotados pelas diferentes escolas teológicas do mundo católico. A aplicação das decisões disciplinares, porém, entrou em choque com os hábitos e abusos de toda ordem que predominava na hierarquia eclesiástica. ${ }^{6} \mathrm{~A}$ reforma moral e intelectual do clero preconizada por Trento, portanto, não se deu imediatamente; da mesma forma a reforma dos costumes da população. Foram necessários alguns séculos para que a Igreja conseguisse atingir estes dois grupos: o clero e os fiéis.

A concepção da aplicação tardia dos dispositivos tridentinos não é apoiada por Ronaldo Vainfas, segundo este autor a aplicação sistemática dos decretos tridentinos na Europa, embora seja típica do século XVII, espalhara-se desde o século XVI por todo o território europeu. Na França, as resoluções de Trento sofreram alguma resistência por parte da monarquia, mas na Europa Meridional foram imediatamente acolhidas. Na Espanha, Felipe II as recebeu triunfalmente, ainda que sob a reserva das prerrogativas reais. Em Portugal, o alvará de 12 de setembro de 1564 recomendou a adoção das medidas 
A MISSA E A FÁBRICA: TENTATIVAS DE CONTROLE DOS ESPAÇOS...

tridentinas e numerosos sínodos encarregaram-se de adaptar as constituições da Igreja lusitana às resoluções do dito Concílio. ${ }^{7}$

A chegada da reforma tridentina na América portuguesa perpassa a análise de muitos historiadores que se ocupam do período colonial. Para Vainfas a reforma tridentina chegou à Colônia com a Companhia de Jesus, Ordem modelo desta reforma. Desde o século XVI Igreja e Estado empenharam-se na difusão do projeto moralizador tridentino na península Ibérica através, principalmente, dos inacianos e do Santo Tribunal da Inquisição. Contudo, a análise do autor sobre a sociedade colonial, desde o século XVI até o XVIII, apontou para o fracasso da reforma tridentina, segundo ele "no trópico lusitano, colonizada à base da miscigenação racial e cultural, ocupado à base de muitos degredos e à custa de 'muitos perdões', como diria certo bispo quinhentista, a cruzada tridentina iria mesmo fracassar." 8

O fracasso da reforma tridentina na Colônia foi afirmado por inúmeros historiadores do período. Alguns autores explicam esse fracasso através do regime do Padroado. De acordo com o Padroado, os monarcas portugueses tinham a obrigação de criar as unidades eclesiásticas coloniais, sustentar o clero e os bispos, bem como manter monetariamente o culto. Tais despesas da Coroa viriam do direito de arrecadação e administração dos dízimos da Colônia. ${ }^{9}$

Segundo Oliveira Torres, a posição subserviente da Igreja transformou o clero em uma corporação de servidores do rei para os negócios eclesiásticos, caracterizando-o como "uma burocracia que não vivia a religião". ${ }^{10}$ Somado ao aspecto de subserviência da Coroa, a pouca exemplaridade do clero no aspecto moral é bastante destacada pela historiografia colonial até se tornar uma afirmação clássica. ${ }^{11}$

De tais idéias, presente em muitos estudos sobre a atuação da Igreja na Colônia, decorre a afirmação da pouca influência da mesma nesta sociedade. Controlada pelo Estado, com uma estrutura precária e um corpo eclesiástico desqualificado, a religiosidade colonial resultante foi caracterizada pelas manifestações exteriores da fé. Esses aspectos estão presentes 
também nas obras dos historiadores da Igreja ligados a CEHILA $^{12}$. Na visão de Riolando Azzi, embora o Padroado derivasse de concessões feitas pela Santa Sé, essas concessões permitiram que o monarca se tornasse o chefe efetivo da Igreja, prejudicando a atuação da mesma na Colônia. ${ }^{13} \mathrm{~A}$ administração exercida pelo rei redundou, segundo Azzi, na escassez dos bispos, nas longas vacâncias das dioceses e na dependência dos prelados ao poder real. Acarretou também um número pequeno de dioceses que não chegaram a corresponder às exigências do grande território colonial. ${ }^{14}$

A imoralidade clerical, somada à falta de formação consistente e à condição de funcionário público, fez com que, segundo Riolando Azzi, durante todo o período colonial o clero luso-brasileiro mantivesse um modo de vida bem diverso do modelo sacerdotal tridentino. ${ }^{15}$

O conjunto de postulações desses historiadores continua presente nas análises recentes da sociedade colonial. Embora não exista a preocupação em avaliar o afastamento ou aproximação da Igreja da mensagem evangélica - objetivo que perpassa as obras dos historiadores da Igreja e do grupo da CEHILA - percebemos que muitos estudos utilizam-se dos conceitos e conclusões desses historiadores para reafirmar a pouca influência da Igreja na Colônia, bem como a não implantação das diretrizes tridentinas na sociedade colonial. ${ }^{16}$ Dessa forma, as análises historiográficas recentes da sociedade colonial incorporaram preocupações próprias da Igreja, utilizando-as para evidenciar não o afastamento da mensagem evangélica, mas o aspecto de resistência da população e do clero ao poder normatizador da Igreja que pode ser evidenciado por tal interpretação. Tais análises, a nosso ver, estão atreladas à vertente historiográfica que tem como escopo de análise o conflito entre os grupos sociais.

Contudo, há um outro grupo de historiadores que vêem essa questão sob outro prisma. Tais autores indicam o século XVIII como o período em que a Igreja tentou implantar a reforma tridentina na Colônia. Para Leila Mezan Algranti, embora existindo um largo período entre os setecentos e a Reforma 
A MISSA E A FÁBRICA: TENTATIVAS DE CONTROLE DOS ESPAÇOS...

Católica, as disposições tridentinas foram constantemente reafirmadas pela Igreja, inclusive no século XVIII na Colônia. A autora diz que o Concílio de Trento separou duas épocas na história da Igreja católica, a segunda das quais não terminou senão com o Vaticano II. ${ }^{17}$ Caio César Boschi ressaltou que o sínodo diocesano organizado e presidido em 1707 por D. Sebastião Monteiro da Vide, arcebispo da Bahia, foi um evento que dividiu a história eclesiástica brasileira em duas fases. Desse sínodo resultou a publicação das Constituições Primeiras do Arcebispado da Bahia, que constituem a tradução das normas tridentinas para a Colônia. Boschi ressaltou porém que, como antes, ao longo do século XVIII, o Estado interferiu continuamente nos assuntos eclesiásticos. Contudo, advertiu o autor,

Engano pensar que as determinações provenientes de Trento colidissem com o regalismo lusitano; nunca é demais lembrar que este reino ibérico foi um dos poucos países a colocarem em execução, de imediato, tais determinações. Não havia incompatibilidade - antes, houve complementaridade - entre as deliberações tridentinas e o exercício do poder em Portugal; a ortodoxia romana se amoldou aos interesses da política lusíada. ${ }^{18}$

A segunda metade do século XVIII marcou a multiplicação das unidades eclesiásticas nas regiões Centro-Oeste e Sudeste da Colônia. Em 1745 a Coroa portuguesa dividiu o bispado do Rio de Janeiro em mais quatro unidades: dois bispados, um em São Paulo e outro em Mariana, e duas prelazias, com sedes em Goiás e Mato Grosso. Fernando Torres Londoño assinalou que as transformações que a Colônia atravessava na primeira metade do século XVIII reforçaram e tornaram mais necessárias as reformas da Igreja. Entre as transformações referidas pelo autor está o deslocamento do eixo econômico colonial para as regiões centro-oeste e sudeste devido a mineração. ${ }^{19}$

Londoño afirmou também que ao longo do período setecentista houve um incremento do controle episcopal em suas dioceses, através de visitas pastorais mais freqüentes, e 
um incentivo da prática dos sacramentos segundo os moldes tridentinos. Os bispos setecentistas insistiram também na implantação de uma teologia moral para a formação do clero. ${ }^{20}$

Para Lana Lage da Gama Lima ainda que através da Companhia de Jesus e das Visitações Inquisitoriais os valores tridentinos já tivessem chegado às terras coloniais, somente no século XVIII a Igreja ultramarina procurou promover no Brasil, de forma continuada, as condições para o ambicioso projeto de aculturação das massas característico da Reforma católica. Dentre as condições promovidas há o destaque para a multiplicação da estrutura paroquial, o reforço da hierarquia eclesiástica e a reforma moral e intelectual do clero. ${ }^{21}$

A criação da diocese de São Paulo em 1745 insere-se neste conjunto de mudanças e de controle. Por parte do Estado, havia a preocupação em controlar a região aurífera e centralizar a administração civil na capitania do Rio de Janeiro, com a intenção de manter os territórios do Sul ameaçados pelos espanhóis. Por parte da Igreja, o desmembramento da região mineradora do bispado do Rio de Janeiro e a criação da diocese de São Paulo contribuíram para a efetivação do controle dos bispos aos párocos e fiéis de sua diocese. A Igreja que se esforçava nesse período em imprimir na Colônia uma orientação tridentina, encontrou, portanto, na capitania paulista, uma situação favorável. Veremos abaixo como essa orientação incidiu na cerimônia da missa conventual e na administração dos bens patrimoniais das paróquias de São Paulo.

\section{Igrejas: espaços de doutrinação dos fiéis}

Segundo John Bossy, a partir de Trento houve a intenção da Igreja de canalizar a religiosidade popular para o espaço das paróquias. $^{22}$ Pode-se perceber isso pelas determinações da obrigatoriedade dos sacramentos e do seu registro pelos párocos, bem como, pela assistência obrigatória da missa nos domingos e dias santos. Para salvaguardar a freqüência dos fiéis na missa conventual - designação da missa dos domingos e dias 
A MISSA E A FÁBRICA: TENTATIVAS DE CONTROLE DOS ESPAÇOS...

santos - as Constituições Primeiras do Arcebispado da Bahia ordenavam aos párocos que fizessem, antes de iniciar a cerimônia, uma chamada dos fiéis. Para tanto utilizariam o rol dos confessados confeccionados na quaresma. Recomendava-se na legislação que o pároco lesse em voz alta o nome dos fiéis que costumavam faltar à missa. Aos faltantes, as Constituições prescreviam multas pecuniárias e aos presentes concedia quarenta dias de indulgências. ${ }^{23}$ Nas pastorais dos bispos de São Paulo encontra-se presente ordens e advertências em relação a essa prescrição tridentina. Uma ordem de 1751 do segundo prelado de São Paulo, D. Fr. Antônio da Madre de Deus, demonstra a rigorosidade de guardar os domingos e dias santos:

(...) que os moradores, sob as penas da Constituição, nos domingos e dias santos não abram suas lojas para venderem antes da missa, mas depois dela poderão ter meia abertas e cerradas as portas para vender, o que consentimos por algumas circunstâncias, e o que obrar contrário pagará dois mil réis para o meirinho. ${ }^{24}$

Nesses dias, portanto, não deveriam ser exercidas atividades profissionais, possibilitando que a atenção dos fiéis estivesse voltada para a atividade religiosa, particularmente para a cerimônia da missa, que ocuparia parte do tempo do descanso temporal.

François Lebrun lembrou-nos que, embora a missa fosse uma cerimônia coletiva, durante todo o século XVI e na maior parte do século XVII, ela permaneceu sendo a soma de orações individuais. Espectadores passivos, os fiéis eram convidados a passar o tempo da missa da maneira mais devota possível, rezando o terço. Contudo na segunda metade do século XVII e no decorrer do século XVIII, alguns autores espirituais especialmente os padres do Oratório - concordaram em considerar a missa não mais como um simples exercício de devoção individual, mas como o ato essencial do culto que exige a participação de todo o povo reunido. A partir desta concepção surgiram publicações para instruir os fiéis como deveriam "bem 
ouvir a missa", recomendando que todas as orações cessassem quando o padre rezasse e oferecesse o sacrifício por todos. Segundo o autor, no final do século XVII principiaram na França publicações de missais, com o texto litúrgico em latim e ao lado a tradução francesa, a fim de facilitar a participação dos fiéis durante a missa. ${ }^{25}$

Com efeito, embora o Concílio de Trento recomendasse devoção aos sacerdotes para celebrarem a missa, não permitiu que fosse recitada em língua vulgar, confirmando o latim como língua oficial para a cerimônia. Os redatores do Concílio, no entanto, procuraram aproximar os fiéis dos rituais praticados na missa através da utilização de elementos visíveis que criariam uma atmosfera de meditação. Conforme vemos a seguir:

Como a natureza humana é de tal condição que não pode facilmente sem socorros exteriores elevar-se a meditar as coisas divinas, esta é a causa que a Igreja, como piedosa mãe que é, instituiu certos ritos para se recitarem na missa, uns em voz submissa, outros em voz alta. Juntou a isto cerimônias, como bênçãos místicas, luzes, aromas, vestiduras, e outras coisas do gênero, com que se ficasse recomendável a majestade de tão grande sacrifício, e os entendimentos dos fiéis com estes sinais visíveis de religião e piedade se excitassem à contemplação das coisas altíssimas que se ocultam neste sacrifício. ${ }^{26}$

$\mathrm{Na}$ segunda metade do século XVIII, os dirigentes do bispado de São Paulo expediram pastorais e estiveram atentos aos dispositivos de Trento em relação à forma do sacerdote "dizer" a missa, bem como às atividades que deveriam envolver os párocos e os fiéis antes e depois dessa nos domingos e dias santos. Em 1750, o vigário capitular Mateus Lourenço de Carvalho expediu uma pastoral para todo o clero e o povo da diocese ressaltando os elementos que deveriam ser observados pelos párocos na cerimônia da missa. Lembrava o dirigente do bispado "aos sacerdotes a gravidade, pausa, devoção e fervor com que devem celebrar o sacrossanto e tremendo sacrifício do altar, de sorte que sirvam de edificação dos fiéis e lhes aumentem a devoção (...)." ${ }^{27}$ Essa recomendação evidencia sua 
A MISSA E A FÁBRICA: TENTATIVAS DE CONTROLE DOS ESPAÇOS...

intenção de estabelecer uma relação entre o celebrante e os fiéis presentes na missa.

Complementando tal preocupação encontramos uma advertência do visitador Miguel Dias Ferreira, em 1750, na freguesia de Cotia, a qual demonstra a tentativa de modificar a postura dos fiéis no momento da cerimônia:

Louva-se muito ao reverendo pároco a devoção e exercício do santíssimo terço de Maria (...) cantado pelo povo aos domingos e dias santos, porém não se pode louvar, mas antes estranhar, o cantar-se o dito terço dentro da missa conventual, pelo inconveniente que disso resulta aos devotos que querem meditar no santo sacrifício (...) Portanto, ordeno que daqui em diante se cante o terço ou antes ou depois da missa, como é costume em todas as igrejas, e conforme a pastoral registrada neste livro que manda cantar o terço depois da oração mental e não na missa. ${ }^{28}$

Vê-se, portanto, que houve por parte dos dirigentes do bispado paulista uma tentativa de reformar o caráter da celebração da missa na linha dos autores espirituais pós Trento, conforme ressaltou François Lebrun.

Para solenizar a cerimônia da missa importava também advertir os párocos sobre os interesses pecuniários que permeavam essa atividade. Segundo Mateus Lourenço de Carvalho era estranho "a pouca celebridade e menos gravidade com que celebram, e a menor exação nas cerimônias da missa nas quais devem procurar instruir-se, com aplicação e cuidado recomendado no sagrado Concílio tridentino e no novo Lateranense." 29

Com efeito, no Concílio de Trento encontra-se a seguinte recomendação aos sacerdotes:

(...) assaz claro parece, se deve por todo o cuidado e aplicação para esta ação se fazer com a maior limpeza e pureza de coração, e com a maior piedade e devoção exterior possível. (...) ... que os bispos ordinários dos lugares tenham particularíssimo cuidado e estejam obrigados a proibir e abolir [da missa] tudo o que se tem introduzido ou por ambição ou por irreverência (...) 
primeiramente pelo que respeita a avareza, proíbam (...) as importunas e indecorosas petições de esmolas, que antes se lhe devem chamar exações. ${ }^{30}$

Referia-se Mateus Lourenço de Carvalho às recomendações tridentinas no tocante ao espírito de devoção que deveria estar presente no sacerdote no momento da celebração, bem como ao abuso praticado pelos ministros da Igreja em valorizarem menos o sacrifício do altar e mais as esmolas que recebiam. $O$ comportamento dos sacerdotes assemelhava-se, de acordo com o vigário capitular e segundo Trento, a um cobrador de dívidas. Algumas determinações do Concílio de Trento, das Constituições da Bahia e as advertências e/ou privilégios concedidos através das pastorais dos bispos de São Paulo, como veremos a seguir, revelam a preocupação da Igreja em diminuir o número de missas que poderiam ser rezadas por um sacerdote em um mesmo dia. No texto conciliar encontramos referência principalmente ao grande número de missas encomendadas advindas dos legados pios deixados pelos fiéis a fim de livrarem suas almas do purgatório. Esses casos, que resultavam muitas vezes na impossibilidade do sacerdote rezar todas as missas encomendadas, deveriam ser estudados cuidadosamente pelos bispos em concílios diocesanos a fim de decidirem "o que virem ser mais conveniente para honra e culto de Deus e utilidade das igrejas." 31

Legislando sobre esta matéria, as Constituições da Bahia determinaram que não era conveniente a um sacerdote oferecer duas vezes no mesmo dia o sacrifício do altar, pois a missa fora instituída em memória da paixão de Cristo e ele só a padeceu uma vez. Diante disso os redatores das Constituições ameaçaram de prisão e degredo para Angola aos sacerdotes que rezassem mais de uma missa por dia. ${ }^{32} \mathrm{~A}$ pesada ameaça deveria corresponder à dificuldade que enfrentavam os bispos no sentido de coibir os sacerdotes de suas dioceses a aceitarem em suas igrejas encomendas de missas em número superior do que seria possível realizar. Sem dúvida estavam em jogo as esmolas que recebiam para este ofício. Determinar que um 
A MISSA E A FÁBRICA: TENTATIVAS DE CONTROLE DOS ESPAÇOS...

sacerdote rezasse somente uma missa por dia era valorizar a cerimônia no seu sentido religioso. Somente assim os sacerdotes poderiam rezá-las com "a maior limpeza e pureza de coração, e com a maior piedade e devoção exterior possível", como desejara o Concílio de Trento.

A concepção da missa como sacrifício propiciatório aos fiéis vivos e mortos, também presente no texto do Concílio, justificava as inúmeras encomendas das mesmas na intenção de sufragar as penas e pecados cometidos. ${ }^{33}$ Nesse sentido, o dia fixado pela Igreja para comemoração dos fiéis defuntos constituía-se num dia privilegiado para os cristãos encomendarem missas pelas almas no purgatório. O grande número de encomendas motivou o papa Benedito XIV, em 1748, permitir que nesse dia fossem rezadas três missas pelo mesmo celebrante. Todavia, segundo o vigário capitular Lourenço Leite Penteado, somente na primeira os sacerdotes poderiam receber as esmolas costumadas, por conseguinte, as outras duas deveriam ser rezadas gratuitamente e na intenção de todas as almas do purgatório. ${ }^{34}$ D. Fr. Antônio da Madre de Deus, em 1754, também advertia aos párocos de todo o bispado que, segundo a bula do mesmo papa Benedito XIV de 1742, todos os sacerdotes eram obrigados a celebrarem a missa aos domingos sem receber esmolas. A proibição só seria dispensada, segundo o bispo, aos párocos "cuja indigência for tal, que não possam se sustentar sem aceitarem algumas esmolas de missas que disserem aos domingos." 35

Nas pastorais e nas visitas às freguesias os párocos eram instruídos também em relação as outras atividades que deveriam permear o momento da missa. Segundo a pastoral de D. Bernardo Rodrigues Nogueira, de 1746, esse momento deveria ser aproveitado para a instrução da doutrina católica aos fiéis. Lembrava o ordinário a determinação de 1742 do papa Benedito $\mathrm{XIV}$, na qual os sacerdotes eram obrigados a ensinarem a doutrina cristã aos seus fregueses ao menos uma hora em cada domingo. Tal obrigação não poderia ser substituída pelo sermão que o sacerdote proferia dentro da cerimônia da missa. ${ }^{36} \mathrm{Ou}$ seja, a intenção era utilizar a presença dos fiéis nas igrejas para 
instruí-los na doutrina. Tal ordem foi repetida por D. Fr. Antônio da Madre Deus na pastoral de $1751 .^{37}$ Os visitadores também cobravam dos párocos esta obrigação. Em 1754, o visitador Manoel José Vaz deixou registrado nos capítulos da visita em Araçariguama, para o pároco "não se esquecer da doutrina cristã, que deve ensinar todos os domingos e dias santos." ${ }^{38} \mathrm{Em}$ 1772, o visitador Firmiano Dias Xavier, discorreu sobre os pontos principais que o pároco de Cotia deveria incidir em sua instrução dominical, dizia ele "insista principalmente na explicação da santíssima trindade, na encarnação do Verbo, na mediação que temos em Jesus Cristo, advogado nosso para com o eterno Pai; quem ignora estas coisas não se salva." 39

Jean Delumeau destacou que a obrigação da instrução dominical, prescrita por Trento, foi enfatizada repetidamente pelos bispos ao longo dos séculos XVII e XVIII, nos países europeus. $O$ autor ressaltou a insistência dos prelados para que tal instrução fosse realizada fora do sermão da missa, pois, antes da determinação conciliar, a homilia era o principal veículo de instrução doutrinal dos fiéis. ${ }^{40}$ As ordens contidas nas pastorais dos dirigentes do bispado de São Paulo sugerem a tentativa de instaurar uma catequese dominical que deveria atingir todos os fiéis, adultos e crianças, na linha do Concílio de Trento.

Além da catequese dominical o momento da missa deveria ser utilizado também pelos párocos para realizar práticas espirituais com os fiéis. D. Bernardo Rodrigues Nogueira, em 1746, explicou como os párocos procederiam nessa atividade:

(...) devem também procurar cuidadosamente o exercício da oração mental antes, ou depois da missa logo proximamente, e na mesma igreja ou capela com distinção de lugar para as pessoas conforme o sexo, lendo-lhes o ponto, explicando o que é oração mental, invocando primeiro o divino Espírito, e depois da meditação e de expor o fruto que dela se há de tirar, concluir com algumas jaculatórias e deprecativas orações, no que tudo gastará o tempo que permitir a ocasião, qualidade e circunstâncias das pessoas. ${ }^{41}$ 
A MISSA E A FÁBRICA: TENTATIVAS DE CONTROLE DOS ESPAÇOS...

Vê-se na instrução do prelado a intenção de preencher os momentos em torno da missa por uma atmosfera espiritual de oração entre os fiéis e o pároco. A criação dessa atmosfera dependeria da sensibilidade do pároco, o qual deveria perceber o momento propício para iniciar e encerrar a atividade com seus fregueses. Tal recomendação demonstra um outro aspecto da orientação dos bispos na diocese paulista, a qual prevê um espaço para uma vivência interiorizada da religião. O exercício da oração mental antes ou depois da missa foi ordenado também pelo vigário capitular Lourenço Leite Penteado em 1749, e em 1751, por D. Fr. Antônio da Madre de Deus, "nas igrejas em que comodamente se puderem fazer" ${ }^{42}$. Essa prática era incentivada nas visitas pastorais, conforme atestam os capítulos de visita deixados por Manoel José Vaz na freguesia de Araçariguama e por Luiz Teixeira Leitão em Santo Amaro. ${ }^{43}$

Além da oração mental os párocos deveriam recitar nesses momentos, outras orações com os fiéis. O visitador Antônio José de Abreu deixou registrado, em 1768, na freguesia de São Roque o seguinte capítulo de visita:

Além das mais obrigações fará o reverendo pároco os três atos de fé, esperança e caridade, explicando em voz alta, clara e pausada, para que o povo vá repetindo as mesmas palavras; porque sendo estes atos necessários para a salvação como uniformemente afirmam os teólogos, ainda que variem no tempo em que se deve fazer $(\ldots)^{44}$

O visitador afirmou que a obrigação de recitar as orações estava conforme a bula do papa Benedito XIV de 1742, a qual determinava que os párocos deveriam fazer os atos de fé, esperança e caridade em todos os dias festivos, assim que acabassem de dizer a missa conventual. Para recitá-los os párocos ajoelhar-se-iam no supedâneo do altar, segundo o visitador. Contudo atendendo às muitas obrigações dos sacerdotes no momento da missa, ressalvou Antônio de Abreu que essa obrigação se realizasse ao menos uma vez por mês. ${ }^{45}$ 
Sem dúvida eram muitas as atividades que permeavam o momento da missa, as quais alongavam a permanência dos fiéis na igreja nos domingos e dias santos. Além dessas acima indicadas havia ainda a recitação do rosário, ou ao menos do terço, em louvor à Nossa Senhora. Na pastoral de 1746, D. Bernardo Rodrigues Nogueira recomendou que os fiéis recitassem o rosário diariamente, "além do que, se deve cantar na igreja por todos depois da oração mental" ${ }^{46}$

A devoção à Nossa Senhora com a oração do rosário ou do seu terço encontra-se presente em quase todas as pastorais dos dirigentes do bispado que se relacionam com as práticas espirituais. A recomendação era que se rezasse essa oração todos os dias, mas não podendo, ao menos nos domingos e demais dias santos.

A desejada permanência dos fiéis nas igrejas nos domingos e dias santos não poderia ser causa de escândalos. As igrejas, enquanto espaços de doutrinação e de práticas de orações, deveriam erigir-se em lugares exemplares da conduta cristã. Nas freguesias onde se cantava o terço todos os dias, não só nos domingos e dias santos, os visitadores advertiam sobre a presença de homens e mulheres à noite. ${ }^{47}$

Os capítulos de visita pastoral transmitiam também ordens para que os párocos proibissem a proximidade dos leigos junto ao altar onde estava sendo realizado a cerimônia da missa, bem como advertissem àqueles que depositavam os chapéus sobre os mesmos altares ${ }^{48}$. O barulho das conversas dentro das igrejas também provocou a advertência do visitador Firmiano Dias Xavier, em $1772 .^{49}$ Dessa forma, a desejada e obrigatória permanência dos fiéis nas igrejas nos domingos e dias santos parece ter sido matéria de grande preocupação para os dirigentes do bispado paulista. Desejava-se a presença de todos os fiéis na missa, todavia, essa presença deveria estar marcada pelo ordenamento dos lugares, pelo silêncio e reverência devidos aos "lugares sagrados". 
A MISSA E A FÁBRICA: TENTATIVAS DE CONTROLE DOS ESPAÇOS...

\section{Fábricas: administração da vida material das igrejas}

A supervisão e o controle das freguesias passava também pela administração das rendas e do patrimônio das igrejas e capelas. As fábricas das igrejas constituíam-se no órgão local de depósito deste patrimônio, tendo como administradores os fabriqueiros. Guilherme Pereira das Neves, citando Le Bras, explicou que as fábricas, na França, constituíram organizações de provisores e tiveram origem no século XII, contemporaneamente ao nascimento das comunas, traduzindo a vontade dos leigos de defenderem por si mesmos, em substituição aos senhores e curas, os seus interesses temporais e espirituais. Os fabriqueiros de uma igreja eram eleitos por uma assembléia dos habitantes, obrigatoriamente escolhidos entre os paroquianos que mantivessem bons costumes e soubessem ler e escrever. Dentre as tarefas atribuídas para este grupo estava a manutenção do prédio da igreja, a guarda dos bens móveis (devendo-se inventariar todos os anos), a administração dos recursos, arrecadação das receitas e quitação das dívidas, sendo responsáveis pela igreja e seus anexos, incluídas as sepulturas. ${ }^{50}$

Na Colônia, segundo Guilherme Neves, os fabriqueiros não chegaram a constituir uma coletividade, nem gozaram de tanta autonomia, o que não impediu porém que ocorressem disputas entre eles e os párocos, lembrando os conflitos que ocorreram entre estes últimos e as irmandades. ${ }^{51}$ As paróquias e capelas fundadas pelos monarcas recebiam da fazenda real um dote para constituir suas fábricas. Esse dote deveria ser enviado todos os anos aos fabriqueiros, responsáveis, segundo as Constituições da Bahia, pela administração destes recursos. ${ }^{52}$ No caso das capelas erigidas por leigos, ordenavam as Constituições que os fundadores deveriam dotar ao menos de seis mil réis as fábricas todos os anos. Além disso, parte das taxas cobradas por ocasião das missas festivas e fúnebres, enterros, multas e rendas territoriais pertenciam à fábrica da igreja.

Uma das primeiras medidas de D. Bernardo ao chegar ao bispado de São Paulo foi ordenar, através da pastoral de 13 de 
dezembro de 1746, sobre os livros de tombo e sobre a administração dos fabriqueiros das igrejas. $O$ prelado discriminou didaticamente os passos a serem dados pelo pároco para tomar as contas das fábricas de sua igreja:

(...) cada um dos reverendos párocos tomará ex-ofício e fará logo dar as contas da fábrica, confrarias ou irmandades da sua igreja, e se lançarão nos livros competentes (...) na forma seguinte: Contas de tal ano, em que foi fabriqueiro ou tesoureiro F. Dadas [para] F. que lhe sucedeu; e a sua receita, despesas e sobras consta das verbas abaixo (colocar receita). Pelas sobras do ano e contas antecedentes, que houve o fabriqueiro ou tesoureiro $\mathrm{F}$. antecessor, tanto. Portanto, anualmente recebe a fábrica da fazenda real tanto, (...) pelo que despendeu em tal obra tanto. (...) E assim continuará toda a despesa. (...) [e] se vê ficar de sobras líquidos neste ano para a fábrica tanto, que recebeu o novo fabriqueiro, e ambos assinarão com o reverendo pároco, que na forma sobredita aprovou esta conta. ${ }^{53}$

Após esta prestação de contas das fábricas dos anos anteriores, sendo tudo registrado no livro de tombo da freguesia, deveria o novo fabriqueiro em três meses arrecadar e pagar as parcelas que ainda estavam em débito no seu ano. Caso houvesse negligência do fabriqueiro nas cobranças as despesas da fábrica seriam pagas por seus próprios bens. Em seguida ordenou D. Bernardo aos fabriqueiros listarem nos livros de tombo as rendas das fábricas provenientes das missas perpétuas ou anuais deixadas em testamento, discriminando a verba do testamento destinada a tais missas, as pessoas que eram administradoras dos bens do testamento, os dias e o lugar em que deveriam ser rezadas as missas, ou se não tinham dia ou lugar certo. Esse levantamento das obrigações perpétuas ou anuais seria copiado em folhas avulsas, pregadas numa tábua e pendurado na sacristia da igreja, onde seria averiguado pelos visitadores. ${ }^{54}$

A função do pároco era cobrar do fabriqueiro clareza e retidão na administração das fábricas das igrejas. Primeiramente as contas seriam aprovadas pelos párocos e remetidas para a 
A MISSA E A FÁBRICA: TENTATIVAS DE CONTROLE DOS ESPAÇOS...

câmara episcopal. Tal esforço de organização e registro dos bens temporais das igrejas seria perseguido pelos prelados de São Paulo em todas as administrações. Em 1751 D. Fr. Antônio da Madre de Deus expediu uma pastoral reafirmando as ordens do seu predecessor ${ }^{55}$, e em 1754 Manoel José Vaz realizando visita pastoral na freguesia de Araçariguama, nomeado por D. Fr. Antônio, novamente ordenou,

Todos os anos tomará o reverendo pároco contas aos fabriqueiros da receita e despesas guardando a formalidade, distinção e clareza (...) que a este respeito mandava o senhor bispo D. Bernardo Rodrigues Nogueira (...) sob pena de se haver por seus bens o prejuízo que por esta falta acontece a fabrica da igreja. Para fim de se evitar confusão, que na presente visita deu causa ao trabalho de rever as contas de todos os fabriqueiros, menos as do atual, que se acham lançados com a clareza que muito se lhe louvam, e se espera do seu zelo continue com a mesma devoção na esperança de alcançar de Deus pelo seu trabalho o prêmio dos que servem a Igreja. ${ }^{56}$

D. Fr. Manuel da Ressurreição, realizando pessoalmente as visitas pastorais na diocese de São Paulo, constatou na freguesia de São Roque e de Cotia a confusão nas administrações das fábricas,

Achamos o livro da receita e despesa da fábrica com muito pouco ou nenhuma digestão e totalmente confuso; por isso mandamos que daqui por diante se façam lançar as adições assim da receita, como da despesa (...) e que o reverendo pároco tome anualmente as contas do fabriqueiro... ${ }^{57}$

Em Araçariguama, no mesmo ano, o bispo D. Fr. Manuel da Ressurreição ordenou o levantamento das obrigações perpétuas das fábricas. Referia-se o prelado aos legados deixados em testamento para a igreja da freguesia pelos fiéis Maria Pires de Camargo e Rodrigo Bicudo Chassim. Advertiu D. Fr. Manuel que os juros destes legados não estavam sendo cobrados pelo fabriqueiro, dessa forma, ordenou ao mesmo que os cobrasse e 
os aplicasse em azeite para a lâmpada na semana santa e na realização da festa de Nossa Senhora da Penha, padroeira da freguesia. Contudo, advertiu o bispo:

Como a igreja necessita de algumas obras mais precisas, como são: o corredor da parte em que está a escada que vai para o coro, e o conserto do forro da capela mor, advertimos o reverendo pároco que cuide com toda a gravidade em tudo isto para o que aplicamos os juros todos que até agora tem rendido os duzentos e cincoenta mil réis acima declarados para as ditas obras e conserto. ${ }^{58}$

Essas repetidas recomendações, nas visitas e nas pastorais, ordenando aos párocos tomarem as contas dos fabriqueiros, pode indicar que, ou existia negligência dos párocos nesta matéria, ou havia dificuldade na relação entre párocos e fabriqueiros. Percebemos que a intenção dos bispos era subordinar as atividades dos fabriqueiros aos párocos, pois estes eram os responsáveis por providenciar os reparos das partes danificadas dos prédios das igrejas, contando para isso com as rendas das fábricas. É interessante notar que essas rendas não financiavam somente as obras materiais, mas também sustentavam o culto nas igrejas, como as festas dos santos ou o material necessário para as missas.

\section{Conclusão}

Analisamos neste artigo dois aspectos centrais para a prática da evangelização da Igreja colonial no bispado de São Paulo, ou seja, o exercício de difusão da doutrina católica a partir das paróquias e a administração material dos prédios das igrejas. Achamos conveniente destacar esses dois temas, entre muitos outros contidos nos documentos escolhidos, porque a intenção de estruturar as atividades religiosas em torno das paróquias, colocando o pároco como centralizador desse processo, é uma prerrogativa marcante no Concílio de Trento. 
A MISSA E A FÁBRICA: TENTATIVAS DE CONTROLE DOS ESPAÇOS...

As ordens e advertências dos bispos, dos vigários capitulares e dos visitadores da diocese de São Paulo baseavamse, como foi demonstrado, nos cânones tridentinos. Vê-se isso não apenas na tentativa de impor devoção na cerimônia da missa como também na forma de administrar e resguardar o patrimônio das igrejas. Nos dois aspectos os párocos são colocados como os agentes executores da reforma pretendida por Trento. Contudo, a responsabilidade de ordenar, supervisionar e punir os que não cumpriam os preceitos conciliares era dos bispos e, no caso de sede vacante, dos vigários capitulares. As visitas pastorais foram resgatadas pelo concílio tridentino e tornaram-se um importante instrumento das dignidades episcopais para a verificação das atividades desenvolvidas pelos párocos e pelos fiéis conforme foi demonstrado.

Em relação ao aspecto doutrinal destaca-se nas pastorais e nos capítulos de visita a orientação dos dirigentes do bispado sobre a forma dos sacerdotes de celebrarem a missa aumentando-lhes a devoção. Veiculou-se também através destas correspondências normativas a determinação tridentina sobre a presença obrigatória dos fiéis nessa celebração. A recomendação de cessarem as orações pré-estabelecidas no momento da missa, a ordenação dos lugares dos fiéis dentro das igrejas e o silêncio que deveria ser observado pelos mesmos revelam a preocupação dos bispos em solenizar o momento dessa cerimônia e atestam a tentativa de estabelecer o caráter coletivo da celebração conforme Trento.

À obrigatoriedade da presença dos fiéis na missa somavase, segundo determinação conciliar, à também obrigatória instrução dominical pelos párocos. Além disso, observamos que no bispado de São Paulo houve o incentivo às práticas de oração. Nesse sentido, o momento da missa tornou-se um meio para orientar os fiéis no caminho de uma espiritualidade mais profunda. Ainda que houvesse a reafirmação das orações vocais, como a recitação do terço e outras orações pré-estabelecidas, o incentivo da oração mental revelou traços de uma espiritualidade menos metódica e ritualística. Ou seja, uma 
oração interior que valorizasse o contato íntimo da consciência dos fiéis com Deus, concepção que estava de acordo com os reformadores espirituais europeus, especialmente os padres oratorianos, no mesmo período.

As fábricas, aspecto abordado brevemente nesse texto, incidia sobre a administração material das igrejas e capelas. Tal administração era também avaliada nas visitas pastorais. Nos capítulos das visitas encontramos advertências sobre a precariedade dos prédios das igrejas, sobre a falta de ornamentos e alfaias para as cerimônias religiosas, bem como sobre a administração das rendas das fábricas. Notamos o esforço dos bispos em submeter as atividades dos fabriqueiros, que em geral eram leigos, ao controle dos párocos. As rendas desses pequenos órgãos administrativos provinham de duas fontes na Colônia: através da Coroa portuguesa, quando fundava uma igreja, provendo-a de um dote anual e através dos leigos quando deixavam em testamento missas encomendadas pela sua alma, além disso uma porcentagem das taxas que o pároco recebia na administração dos sacramentos deveria também compor as rendas das fábricas.

A dotação das igrejas pela fazenda real dava-se em razão do direito do Padroado, conforme foi apontado no início desse texto. Tal direito adquirido pelos monarcas portugueses na época da expansão marítima vigorou em todo o período colonial. Aos monarcas foi concedido pelos papas o poder e a obrigação de fundar novas igrejas, criar dioceses, nomear pessoas para os cargos eclesiásticos e em troca o rei detinha o direito de administração dos dízimos das regiões colonizadas. Era, portanto, da fazenda real que deveriam provir todo o necessário para a manutenção material das igrejas, inclusive para o pagamento dos benefícios eclesiásticos. As provisões para a manutenção dos prédios das igrejas seriam depositadas nas fábricas, sendo administradas por leigos com o controle do pároco. Notamos, contudo, duas dificuldades nesse processo: os dotes das fábricas não se mostraram suficientes às necessidades materiais das igrejas e, por outro lado, os párocos 
A MISSA E A FÁBRICA: TENTATIVAS DE CONTROLE DOS ESPAÇOS...

tinham dificuldade de submeter as atividades dos fabriqueiros à sua autoridade como ordenavam os bispos.

Ao finalizarmos, concluímos que em relação aos temas analisados, a orientação tridentina esteve presente nas medidas tomadas pelos bispos e pelos vigários capitulares da diocese de São Paulo na segunda metade do século XVIII. Suas repetidas ordens e advertências revelam um esforço contínuo no intuito de reformar nos párocos e na população as atividades religiosas e administrativas segundo os parâmetros tridentinos, bem como, de tornar as paróquias os órgãos centralizadores desse processo.

ZANON, Dalila. The Mass and the factory: attempts to control the spaces of São Paulo churches by their colonial bishops (1745 1796). História, v.28, n.2, p.79-106, 2009.

Abstract: The pastoral letters of the colonial bishops and the registered chapters of pastoral visits in the bishop's tumble books, both located in the bishop's towns, tell us, among other subjects, about the implementation of tridentine decrees in the Setecentista Colony. Such decrees, proceeding from the Concil of Trent and carried through by the Catholic Church in the $16^{\text {th }}$ century, had to guide the performance of all the elements of the ecclesiastical hierarchy in the catholic kingdoms. The bishops were responsible for the implantation of the tridentines' devices, and for their execution. They were also responsible for demanding that all the scope of its jurisdiction was observed. When reading and analysing the pastoral visits in São Paulo between 1745 and 1796 - we find an episcopal orientation lined up with the tridentine decrees. In this article we will focus on two aspects of the administration of São Paulo bishops: the ceremony of the Mass and the administration of the church factories.

Keywords: Catholic Church; Bishops of $18^{\text {th }}$ century ; Pastoral letters. 


\section{NOTAS}

${ }^{1}$ A autora fez uma revisão historiográfica sobre a reforma no item "Reforma Católica: um novo conceito". Cf. LIMA, Lana Lage da Gama. A Confissão pelo Avesso: o crime de solicitação no Brasil Colonial, São Paulo, 1990. Tese (Doutorado em História) USP, pp. 163-176.

2 A Devotio Moderna nasceu segundo Delumeau no século XIV. O movimento apregoava a meditação pessoal sobre a vida de Cristo, bem como a tentativa de imitação da vida de Jesus. Segundo a autora Leila Mezan Algranti, a Devotio Moderna influenciou também a vida das religiosas em Portugal no século XV. Destacou a autora que nos conventos elas viviam sob a doutrina da imitação de Cristo, que consistia no recolhimento, mortificação e na referência constante à fé e virtudes cotidianas. A G. Dickens apontou para a influência deste movimento de espiritualização na vida dos leigos como os Irmãos da Vida Comum. Foi um movimento de renovação dos cônegos agostinhos na Holanda que reagrupou leigos e clérigos aceitando uma regra, mas conservando a liberdade de cada um seguir sua vocação pessoal. $\mathrm{Na}$ Itália foi fundado Oratório do Amor Divino no final do século XV por iniciativa de um leigo, na qual se acentuava a oração, a santificação pessoal e o serviço à comunidade. Delumeau destacou as conversões pessoais dos bispos, antecedentes ao século XVI, como movimento que impulsionou a Reforma Católica. Dentre eles Gian Matteo Giberti, bispo de Verona, o qual criou um modelo para a reforma dos bispos da Itália e que foi seguido por Trento; na França Guillaume Briçonnet e em Toledo Francisco Ximenéz Cisneros. Cf. DELUMEAU, Jean. El Catolicismo de Lutero a Voltaire, trad. Miguel Candel, Barcelona: Labor, 1973, pp. 3-6; ALGRANTI, Leila Mezan. Honradas e Devotas: Mulheres da Colônia, Rio de Janeiro: José Olympio, 1993, pp. 27-28 e DICKENS, A. G. A Contra-Reforma, Lisboa: Verbo, 1972, pp. 66-67.

${ }^{3}$ DELUMEAU, Jean. Op. cit., pp. 199-210.

${ }^{4}$ KARNAL, Leandro. Teatro da Fé: Representação Religiosa no Brasil e no México do século XVI, São Paulo: Hucitec, 1998, pp. 44-45.

${ }^{5}$ DELUMEAU, Jean. Op. cit., p. 34.

${ }^{6}$ idem, p. 33.

${ }^{7}$ VAINFAS, Ronaldo. Trópico dos Pecados, Rio de Janeiro: Campus, 1989, p. 13.

${ }^{8}$ idem, p. 346. 
A MISSA E A FÁBRICA: TENTATIVAS DE CONTROLE DOS ESPAÇOS...

${ }^{9}$ Para maiores detalhes sobre o regime do padroado português cf. "Vicissitudes da criação da diocese paulista" in ZANON, Dalila. A ação dos bispos e a orientação tridentina em São Paulo (1745-1796), Campinas, 1999. Dissertação (Mestrado em História), Unicamp, pp. 2427.

${ }^{10}$ TORRES, João Camilo de Oliveira. História das Idéias Religiosas, São Paulo: Grijalbo, 1968, p. 39.

${ }^{11}$ Lana Lage ressaltou que desde Gilberto Freyre o aspecto pouco moral do clero colonial passou a ser evidenciado. O historiador Charles Boxer confirmou esta visão, explicando que as dificuldades encontradas pela Coroa portuguesa para arregimentação do clero na evangelização das terras no além-mar fizeram com que fosse transportado para estes lugares padres indisciplinados e até criminalmente condenados. Cf. LIMA, Lana Lage da Gama. op. cit., pp. 339-340. A idéia do degredo está presente também em estudos mais recentes como o de Vainfas, conforme apontamos acima.

${ }^{12}$ A CEHILA (Comissão de Estudos da História da Igreja na América Latina) foi criada no ano de 1973, com o intuito de refazer a história da Igreja na América Latina a partir do pobre e do oprimido. Essa visão da Igreja foi inaugurada na América Latina a partir do Concílio Vaticano II, o qual marcou a opção preferencial da Igreja pelos pobres. Tal opção encontrou respaldo teórico na teologia da libertação, divulgada por teólogos brasileiros como Fr. Betto e Fr. Leonardo Boff. As produções historiográficas da CEHILA, iniciadas na década de 70, são marcadas portanto, por esta postura que a Igreja assumiu na América Latina a partir desta década. Alguns autores podem ser citados como representantes desta corrente: Eduardo Hoonaert, Riolando Azzi e Oscar Beozzo.

${ }^{13}$ AZZI, Riolando. "A instituição eclesiástica durante a primeira época colonial", in HOORNAERT, Eduardo. Et al, História da Igreja no Brasil, tomo 2, Petrópolis: Vozes, 1977, p. 164.

${ }^{14}$ idem, p. 172.

${ }^{15}$ AZZI, Riolando. O clero no Brasil: uma trajetória de crises e reformas, Brasília: Rumos, 1992, pp. 23-24.

${ }^{16}$ Alguns autores que exemplificam essa abordagem são: VAINFAS, Ronaldo. Op. cit.; PRIORE, Mary Del. Ao Sul do Corpo: condição feminina, maternidades e mentalidades no Brasil Colônia, Rio de Janeiro: José Olympio, Brasília: Edunb, 1993; SOUZA, Laura de Mello e. O Diabo e a Terra de Santa Cruz, 5ª ed., São Paulo: Cia. das Letras, 1995 
e WERNET, Augustin. A Igreja Paulista no século XIX, São Paulo: Ática, 1987.

${ }^{17}$ ALGRANTI, Leila Mezan. Op. cit., p. 31.

18 BOSCHI,Caio César. "As visitas diocesanas e a inquisição na colônia", Revista Brasileira de História, São Paulo, vol. 7, marçoagosto/1987, pp. 159-160.

19 LONDOÑO, Fernando Torres. Público e Escandaloso: Igreja e Concubinato no Antigo Bispado do Rio de Janeiro, São Paulo, 1992. Tese (Doutorado em História), USP, p.182.

${ }^{20}$ idem, pp. 183-184.

${ }^{21}$ LIMA, Lana Lage da Gama. Op. cit., p. 358.

22 BOSSY, John. "The Counter-Reformation and the people of catlholic Europe", Past and Present, maio/1974, pp. 51-70, apud LIMA, Lana Lage da Gama. Op. cit., p. 191.

23 Constituições Primeiras do Arcebispado da Bahia, São Paulo: Typographia 2 de dezembro, 1852, Livro Segundo, tít. XI, parágs. 366 a 370.

${ }^{24}$ Arquivo da Cúria Metropolitana de São Paulo (ACMSP), Pastoral de D. Fr. Antônio da Madre de Deus, 10 de julho de 1751, Livro de tombo da freguesia de Araçariguama (10-1-33), p. 3.

${ }^{25}$ LEBRUN, François. "As reformas: devoções comunitárias e piedade pessoal" in ARIÉS, Philippe e CHARTIER, Roger (org.). História da Vida Privada, trad. Hildegard Feist, vol. 3, São Paulo: Cia. das Letras, 1991, pp. 73-74.

${ }^{26}$ O Sacrosanto e Ecumênico Concilio de Trento. Lisboa: Oficina de Antonio Rodrigues Galhardo, 1807, sessão XXII, cap. V, pp. 97-99.

${ }^{27}$ Arquivo Monsenhor Jamil Nassif Abib, Rio Claro, Cópia xerográfica da pastoral de Mateus Lourenço de Carvalho, 18 de abril de 1750, Livro de tombo da freguesia de Cunha, p. 63v.

${ }^{28}$ ACMSP, Capítulos de visita pastoral de Miguel Dias Ferreira, 3 de janeiro de 1750, Livro de tombo da freguesia de Santo Amaro (2-2-27), p. 59.

${ }_{29}$ Arquivo Monsenhor Jamil Nassif Abib, Rio Claro, Cópia xerográfica da pastoral de Mateus Lourenço de Carvalho, op. cit.

${ }^{30}$ O Sacrosanto e Ecumenico Concilio de Trento. Op. cit., sessão XXII, "Decreto do que se deve observar e evitar na celebração da Missa", pp. 111-113.

${ }^{31}$ idem, sessão XXV, Cap. IV, pp. 427-429. 
A MISSA E A FÁBRICA: TENTATIVAS DE CONTROLE DOS ESPAÇOS...

${ }^{32}$ Constituições Primeiras do Arcebispado da Bahia. Op. cit., Livro Segundo, tít. V, parág. 339.

${ }^{33}$ O Sacrosanto e Ecumenico Concilio de Trento. Op. cit., sessão XXII, cap. II, pp. 91-93.

${ }^{34}$ ACMSP, Pastoral de Lourenço Leite Penteado, 23 de agosto de 1749, Livro de tombo da freguesia de Santo Amaro (2-2-27), p. 57.

${ }^{35}$ ACMSP, Pastoral de D. Fr. Antônio da Madre de Deus, 1 de agosto de 1754, Livro de tombo da freguesia de Araçariguama (10-1-33), p. 15.

${ }^{36}$ ACMSP, Pastoral de D. Bernardo Rodrigues Nogueira, 6 de agosto de 1746, Livro de tombo da freguesia de Cotia (10-2-18).

${ }^{37}$ ACMSP, Pastoral de D. Fr. Antônio da Madre de Deus, 10 de julho de 1751, Livro de tombo da freguesia de Araçariguama (10-1-33), p. 3.

${ }^{38}$ ACMSP, Capítulos de Visita Pastoral de Manoel José Vaz, 29 de outubro de 1754, Livro de tombo da freguesia de Araçariguama (10-133), p. 9.

${ }^{39}$ ACMSP, Capítulos de visita pastoral de Firmiano Dias Xavier, Livro de tombo da freguesia de Cotia (10-2-18), 27 de outubro de 1772, p. 50.

${ }^{40}$ DELUMEAU, Jean. Op. cit., pp. 244-246.

${ }^{41}$ ACMSP, Pastoral de D. Bernardo Rodrigues Nogueira, 6 de agosto de 1746, Livro de tombo da freguesia de Cotia (10-2-18).

${ }^{42}$ Arquivo Monsenhor Jamil Nassif Abib, Rio Claro, Cópia xerográfica da pastoral de Lourenço Leite Penteado, 19 de novembro de 1749, Livro de tombo da freguesia de Cunha, p. 61; ACMSP, Pastoral de D. Fr. Antônio da Madre de Deus, 10 de julho de 1751, Livro de tombo da freguesia de Araçariguama (10-1-33), p. 3.

${ }^{43}$ ACMSP, Capítulos de visita pastoral de Manoel José Vaz, 29 de outubro de 1754, Livro de tombo da freguesia de Araçariguama (10-133), p. 9 e Capítulos de visita pastoral de Luiz Teixeira Leitão, 24 de dezembro de 1761, Livro de tombo da freguesia de Santo Amaro (2-227), p. 81.

${ }^{44}$ ACMSP, Capítulos de visita pastoral de Antônio José de Abreu, 5 de fevereiro de 1768, Livro de tombo da freguesia de São Roque (10-2-18), p. 44.

${ }^{45}$ idem.

${ }^{46}$ ACMSP, Pastoral de D. Bernardo Rodrigues Nogueira, 6 de agosto de 1746, Livro de tombo da freguesia de Cotia (10-2-18).

${ }^{47}$ ACMSP, Capítulos de Visita Pastoral de Antônio José de Abreu, 5 de fevereiro de 1768, Livro de tombo da freguesia de Cotia (10-2-18), p. 44; Pastoral de Manoel José Vaz, 9 de março de 1768, Livro de tombo da 
freguesia de Cotia (10-2-18), p. 48 e Pastoral de Paulo da Souza Rocha, 8 de janeiro de 1795, Livro de tombo da freguesia de Cotia (10-2-18), p. 66.

${ }^{48}$ ACMSP, Capítulos de visita pastoral de Miguel Dias Ferreira, 3 de janeiro de 1750, Livro de tombo da freguesia de Santo Amaro (2-2-27), p. 59.

${ }^{49}$ ACMSP, Capítulos de visita pastoral de Firmiano Dias Xavier, 16 de outubro de 1772, Livro de tombo da freguesia de Santo Amaro (2-2-27), p. 121.

50 NEVES, Guilherme Pereira das. E Receberá Mercê: A Mesa da Consciência e Ordens e o Clero Secular no Brasil, 1808-1828, Rio de Janeiro: Arquivo Nacional, 1997, pp. 227-228.

51 idem.

52 Constituições Primeiras do Arcebispado da Bahia. Op. cit., Livro quarto, tít. XXV, parág. 720, 721.

53 ACMSP, Pastoral de D. Bernardo Rodrigues Nogueira, 13 de dezembro de 1746, Livro de tombo da Sé (2-2-17), p. 1.

${ }^{54}$ idem.

${ }^{55}$ ACMSP, Pastoral de D. Fr. Antônio da Madre de Deus, 10 de julho de 1751, Livro de tombo da freguesia de Araçariguama (10-1-33), p. 3.

${ }^{56}$ ACMSP, Capítulos de Visita Pastoral, 29 de outubro de 1754, Livro de tombo da freguesia de Araçariguama (10-1-33), p. 9.

${ }^{57}$ ACMSP, Capítulos de Visita Pastoral, 17 de abril de 1776, Livro de tombo da freguesia de São Roque (10-3-25), p. 34; Capítulos de Visita Pastoral, 13 de abril de 1776, Livro de tombo da freguesia de Cotia (102-18), p. 55.

${ }^{58}$ ACMSP, Capítulos de Visita Pastoral, 12 de maio de 1776, Livro de tombo da freguesia de Araçariguama (10-1-33), p. 50.

Artigo recebido em 01/2009. Aprovado em 06/2009. 